\title{
C00-3017-25
}

\section{RADIATION CARCINOGENESIS}

\author{
PROGRESS REPORT III \\ 15 MARCH 1975 - 15 MARCH 1976
}

SHIELDS WARREN AND OLIVE GATES

\author{
NEW ENGLAND DEACONESS HOSPITAL \\ CANCER RESEARCH INSTITUTE \\ 185 PILGRIM ROAD \\ BOSTON, MASSACHUSETTS 02215
}

MARCH 1976

PREPARED FOR

THE U.S. ENERGY RESEARCH AND DEVELOPMENT ADMINISTRATION UNDER CONTRACT E(11-1)-3017 


\section{DISCLAIMER}

This report was prepared as an account of work sponsored by an agency of the United States Government. Neither the United States Government nor any agency Thereot, nor any of their employees, makes any warranty, express or implied, or assumes any legal liability or responsibility for the accuracy, completeness, or usefulness of any information, apparatus, product, or process disclosed, or represents that its use would not infringe privately owned rights. Reference herein to any specific commercial product, process, or service by trade name, trademark, manufacturer, or otherwise does not necessarily constitute or imply its endorsement, recommendation, or favoring by the United States Government or any agency thereof. The views and opinions of authors expressed herein do not necessarlly state or reflect those of the United States Government or any agency thereof. 


\section{DISCLAIMER}

Portions of this document may be illegible in electronic image products. Images are produced from the best available original document. 
$000-3017-25$

\section{RADIATION CARCIMOGEWESIS}

Progress Report III

Shields Warren and Olive Gates

Ner England Deaconess Fospital

Cancer Research Institute 385 Pilgris Road

Boston, Massachusetta 02215

15 March 1975 through 15 March 1976

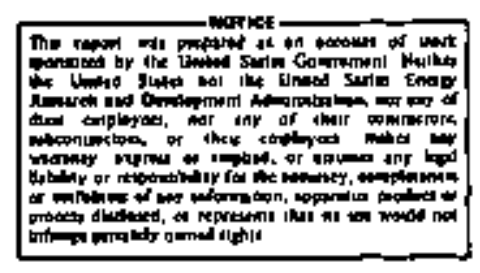

Prepared for the U. S. Energy Research and Development Administration Under Contract No. E(Il-l) -3017 
Members of project. . . . . . . . . . . . . . . . . 1

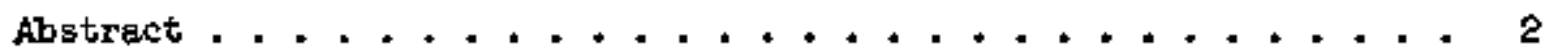

Notice ................................... 4

Statement of Time or Effort of the Frincipal Investigator. . . . . 5

Introduction ........................ 6

Main Research Accomplishmeats. . . . . . . . . . . . . . . 8

The Turarigenic Effects of Acutely Delivered

High Doses in Parablotic Rats. .................. 8

The Pathologic and Tumorigenic Effects on Specific Tissues

of Verious Doses of Radiation to Mice and Rats and

Analysis of the Influence of Hormonel and Other Factors. . . . . . 9

The Interplay of Rediation and Asbestos as Carcinogens

in Botb Single and Parabiont Rodents .............. 12

Physiologic Effects of some Radiation-induced Endocrine Turors . - 12

Irradiated Transplants of Humen Cancer Cells . . . . . . . . 13

Publicstions ............................ 14 


\section{U. S. ENERGY RESEARCH AND DEVELOPNENT ADMTNISTRATION}

Contract E(11-1)-3017

NEMBERS OF PROJECT

15 Marek 1975 through 15 March 1976

STAFF

Princ1pal Investigators:

Shields Warren, M. D.

Olfve Gates, M. D.

Consultants:

\$

Clark E. Brown, M. D.

Russell F. Cowing

Olive M. Lomberd, M. S.

Supporting Personnel:

Rosanna H. Chute, M. A.

Natalie E. Fosseti, B. S. in B. A.

Ruth A. Marshall

Roberta O'Brlen

Marilyn W. Porter, B: A. 


\section{ABSTRACT}

- The attention of forensic pathologists bas been drawn to the criteria essential for the recognition of radiation death or injury in the hope that such cases will be better recognized and thet some false clasns of radiation danige mitht be prevented at the local level.

The results of our experimeats have beed as follows.

The series of parabiont rats one of which had been irradiated with $1000 \mathrm{R}$ of $250 \mathrm{kVp} \times-\mathrm{ray}$, the other shielded, has been completed. With controls and related 樶ial studies the total is over 3000 pairs equaliy divided as to sex. Some specialized bistologic studies remain to be completed. Hhch information on the relative sensitivity of different tissues and organs to tumor induction is available and is being statistically analyzed. These experiments have provided further evidence of the effectiveness of parabiosts in assuring survival after $1000 \mathrm{R}$ $x$-radiation and have enabled us to learn of the typea of problens tbat might be expected in the way of late effects in heavily irzediated 1ndtviduals should they be enabled by effective therapy to survive the acute phases of the radiation syndrome.

Additional evidence has been brougbt out that carc1nogenesis in some hormonally dependent tiasues and orgens is not so much a direct effect of radiation es it is a sumation of this effect and of alterations caused by changes in hoxmonal balance brought about by the raaiation.

We have found unilateral nephrectomy of each rat of a parabiont pair followed by radiation of one of the pair to augatent the hormonal imbalance. This results in a very high Incidence of carcinomia of the breast in females, not in the trradiated animal but in the unirradiated. 
Evidence has long existed that functional change occurs in the adrenal cortex following radiation. There bas, however, been little evidence of morphologic changes other than a direct destructive effect on cells at high dose levels. In irradiated mice in dose levelo from 30-500 rads we have found proliferation of "A" cells, an established preneoplastic change. Hot only this chenge but some tumors of the adrenal cortex have been produced altbough the adrenal gland is in general radioresistant. This change, which tends to occur in some aging mice, is accelerated and enhanced by radiation.

The laterplay of radiation effect on Iung and pleura with their inflamatory reaction to asbestos has been carried through the prelimInary phases, and a number of the experimental animals have been prepared. Incident to the experiment we hope to obtain data on the relative carcinogenic effects of Cenadian and Rhodesian asbestos and other important insulating materials.

Further studies have been made of metabolically active tumors induced by radiation in rats and mice. Tho have proved of special experimental value-a pheochromocytoma and an insulfnoma. Both are readily transt plantable in rats and produce large anourts of the respective hormones. 
- This report was prepared as an account of work aponsored by the United States Government. Neither the United States nor the United States Energy Research and Development Administration, nor any of their employees, nor any of their contractors, aubcontractors, or their employees, makes any warranty, express or implied, or assumes any legal liabizity or responsibility for the accuracy, completeness, or usefulness of any information, apparatus, product or process disclosed or represents that its use would not infringe privately owned rights. 
During the current year of the project, the Principal Investigator, Shields Warren, M. D., Member at the Cancer Research Institute, has spent $20 \%$ of his time devoted to the research of this project.

It is expected that during the coming year, Dr. Harren will cantinue to spend $20 \%$ of his time on this project. 


\section{TNRRODUCTION}

- The period March 15, 1975 through March 15, 1976 has seen substantial progress in winding up our long-term experinents with irradiated parabiotic rats. Over 6500 histologic slides have been prepared and diagnosed. The data have been assembled on punch cards and several test series analyzed. Some detailed results are given in the articles cited in the 11st of publicetions.

We are deeply indebted to Dr. William V. MeDermott, Jr., Director of the Cancer Research Institute, for provision to us of the facilities of the Institute, especially the excellent Animal Farm without which we could not function. The antmal facilfties of the Harvard Medical school have continued to provide us with inbred pathogen-free rats.

Under a grant from the National Cancer' Institute special study has been given to the effect of radiation on leukemogenests in rets. Results thus far indicate a mild inhibitory ratber then an lnducting effect.

During the year $\mathrm{D} x$. Warren spent 20 percent of his time on the project. Dr. Gates hes continued to devote a major portion of her time as a volunteex which hes greatly facilitated our work. Dr. Clark E. Brown has continued to ald us as consultant in Pathologr, a portion of the time as a volunteer. We are deeply indebted to both.

We are grateful for assistance fron the General Research Support Grant of the Hational Cancer Institute to the New England Deaconess Hospital.

Dr. Warren has called the attention of those concermed w1th forensic pathology to the criteria essential for the recognition of radiation death or 1njuxy in the hope of properly recognizing such cases and of 
preventing at the grassroots the initiation of mistaken elaims for radiatjion infury. He has also continued to serve as a member of the llational Aeronautics and Space Administration's Space Program Advisory Council. $\mathrm{Dr}$. Barren, together with $\mathrm{Dr}$. John $\mathrm{Z}$. Bowers and $\mathrm{Dr}$. Walter D. Claus, was honored at the Workshop on the Blological Effects and Toxicity of 239-Fu and 2a6-Ra sponsored by the University of Utah Division of Radsobiology and the Energy Research and Development Adninistration.

Dr. Warren and Dr. Gates presented a paper on "Leukemogenesis by Low-Ievel Radietion" at the International Atomic Energy Agency Symposium on Blological Effecta of Lov Level Radiation Pertinent to Frotection of Man and His Eatiroument.

Dr. Warren presented a Seminar in Radiobiology at the University of Iowa.

Radiation safety has been maintained with the ald of the Harvard University Environnental Fealth and Safety Services. In adaition, Mr. Russeli F. Cowing has served parttine as a Consultant in radiation safety and in the planning and dosimetry of radiation experimeats. Miss olive $M$. Iombard has continued as Consultant in blostatistics. Fer book, "Blostatisties for the Health Professions," was published in 1975. 


\section{MATH RESEARCB ACCOMPLISHMEHS}

Our experiments duriag this period have been grouped as follows.

A. Radiation Carcinogedesis in Rodents

1. The tumorigente effects of acutely delivered high doses in parabiotic rats.

2. The pathologic and tumorigente effects on apecific tissues of vartous doses of radiation to mice and rats and analysis of the influence of hormonal and otber factors.

3. The interplay of radiation and asbestos as carcinogens in both bingle and parabiont rodeats.

B. Incidental Radiation Effects

1. Fhysiopathologic effects of some radiation-induceâ endocrioe tumors.

2. Irradiated transplants of human cancer cells.

A. 1. The Turoorigenic Effect5 of Acutely Delivered High Doses 1n Parebsotic Rats-This series is now virtually coiplete-over 3000 pairs. The parabiotic pairs dylng during the year provided further evidence of the effectiveness of parabiosis in assuring survival and of hearymose (1000 B) radiation in increasing the incidence of neoplasms. About three fourths of the data have been transferred to punch cards for tabulation and anelysis.

In one subgroup, 1000 reds of acute whole-body $250 \mathrm{kVp} x \rightarrow \mathrm{ray}$ had been delivered to esch member of the pair successively with an interval of 60 days between. The long-term aurvival of the pairs has demonstrated the ability of a supralethally-irrediated rat not only to recover with 
the aid of parabiosis, as is well known, but in turn to be able to support its subsequently irradiated partner. Interestingly enough, these pairs of animals have developed several of the anastonotic line tumors described by us recentiy. 1

A number of parabiosed and irradiated pairs which were separated at various time intervals after irradiation bave died and are being studied to attempt to differentiate between the effects of parabiosis alone and those of radiation. Some of these animals have developed tumors but not a sufficient number have died as jet to permit conclusions to be drawn.

A. 2. The Pathologic and Tumorigenic Erfects on Specific Tissues of Vartonis Doses of Radiation to Mice and Rats and Analysts of the Influence of Horwongl and Other Factors-Gataracts were produced in $75 \%$ of the irradiated members of parabiont patrs one of which had received. $1000 \mathrm{R}$ of whale-body $x$-rediation. The lucldence of cataract in their shielded partners was $0.2 \%$, the sane as in control parabiont pairs. In addition to cataract this dose of radiation produced extensire ophthalmic pathology, including degeneration of the retina with loss of cells in alI layers, marked hyaline thickening of the walls of intraocular blood vessels, and increased deposition of collagen in interstitial tissues. Th1s fact of dawage to other tissueg of the eye, the lens, has not previously been adequately stressed.

İarren, S., Hurst, E. E., Jr., Brown, C. E. and Chute, R. M.: Anastomotic Sarcoma of Irradiated Parabiont Rats. Cancer Res. 32:983-987, 5/1972. 
For some time tbere has been evidence that changes occur in adrenal cortical function following radiation. There has been little in the way morphologic changes to correlate with these observations. A study by Dr. Gates of adrenals of a Zarge number of RAP mice, 700 controls and 900 irradiated, has shows certain cellular changes to be induced particwiarly "A" cell proliferation in the cortex, predominantly in females. This change is a precursor to tumor formation. It occurs spontaneously with aging to a limited extent. It follows gamme and $x$-radiation in $a$ range of dose levels (30-500+ rads) in many animals, especielly fensles. The evidence reinforces the vies that the adrenal coxtex has a high degree of radioresistance. The "A" cell proliferation, tocreased in degree end advenced in time in feuales by radiation, is strongly influenced. by the hormonal, milleu. This is currently being analyzed.

We have continued to give special attention to the development of mamary tumors io ferale parabiont MEDH rats, particularly in carrying further our study of the effect of unllateral nephrectomy in each of the parablosed partuers prior to radiation. Evidence continues to accumulate that the induction of memmary cancer by radiation is strongly influenced by hormonal changes. Preliminary results by radioloumine assay techniques suggest that the Increased Incidence of mamnary tumor observed in the nonirxadiated partaer is related to high prolactin levels, gerhaps incident to impalred pituitary feedback from the damaged ovaries In the irradiated pertner.

Many of our recent experiments in leukemogenesis bave been carried out with the ald of funds granted by the National Cancer Institute. 
Intermittent $x$-radiation of $30 \mathrm{R}$ administered in $3 \mathrm{R}$ doses for ten successive veeks to RAP onice did not increase the incidence of leukeria, but a totel dose of $100 \mathrm{R}$ given at the rate of $10 \mathrm{R}$ weekly sigaiffcantly increased the level. The incidence was only slightly further increased by a threefold greater dose. Continuous perinatal exposure to gamma rays of ${ }^{60} 00$ in doses rauging from $200-1000$ rads ylelded similar and increased inctdences of leukemia.

In contrast with the mouse where leukenia was readily induced by radiation, the rat appears to be resistant. Single rats irradiated within a range of $700-1100 \mathrm{R}$ did not develop more leukenia than the coutrols. Unirradiated parabiotic rats showed a sifght increase (about $4 \%$ ) in incidence of leukenia, but irradiation with $1000 \mathrm{R}$ of one of the pair decreased the incidence of the disease rather than 1ncreased it. Our rindings are congruent with the suggestions atade by Mole ${ }^{2}$ and by other authors summarized by Mayneord ${ }^{3}$ that with doses higher than those giving the peak responses of leukenia the leukenogenic effect of radiation may be diminished through the killing of celis that have either been made leukemic or are susceptible of becorsing leukemic.

We called attention to several examplea of variation in susceptibility to radiation-induced leukemia, manmary cancer and otber tumors

Q Mole, R. H.: In "Proceedings of the Second United Nations International Conference on the Peaceful Uses of Atcmic Baerib," Vol. 22, "Biological Bffects of Radiation," United Nations, New York, 1958, Pp. 145-148. 3yayneord, W. V. and Clarke, R. H.: Carcinogenes1s and Radiation Risk: A Błomathenatical Reconnalssaoce. Brit. J. Radiol. Suppl. 12, 1975, $112 \mathrm{pp}$. 
in different experimental rodent populations further emphasłafng that instrinsic factors lnherent in, any given population group must be con* sidered as well as the radiation stimulus applied.

A. 3. The Interplay of Radiation and Astegtos ss Carctnogens In Both SIngle and Farablont Rodents-UICC standard Canadian and Rhodesian chrysotile samples suspended in physiological seline solution bave been injected intratracheally and Intrapleurally fnto single and parabiont NEDH rats. Intrapleural and intraperitoneal inoculation of asbestos can " be readily done, but intratracheal is difficult because of resultant respiratory problems. ${ }^{4}$ In spite of the difficuities the number of animals requtred by the protocol has been achieved. It has been shown by Sanders at Battelle Pacific Northwest Laboratorfes that fewer lung tumors developed in rats given particulate plutontun and asbestos than in rats etven plutonium alone. We hope to determine the effect of asbestas injection or aspiration plus external xadiation, each a carcinogen in 1ts own right. Also, we are compariag the carcinogenic effects of Canadian and Rhodesian asbestos.

B. 1. Physiologie Effects of some kadiation-induced Endocrine. Tumars-A large range of tumors of endocrine tissue bave been induced in our irradiated rats and mee. A number have proved transplantable, and two of these have been particulariy serviceable for studies of hormonal effecta. One is a functioning pheochronocytome that reproduces the disesse as seen in man characterized by bypertension and myocardial

\footnotetext{
4Sandera, C. L., Jr.: Dose Dxstribution and Neoplasta in the Iung Following Intratracheal Instillation of $239 \mathrm{FuO}_{2}$ and Asbestos. Realth Physics $28: 383-386,4 / 1975$.
} 
damage. Tischler and Greene' have demonstrated that sone of these pheochronocytoma cells respond to aerve growth pronoting factor by developing neural processes. This tumor has been supplied to several Broups of Investigators including one in Switzerland. We also heve available a highly functioning insulsnoma which produces a narked degree of byperinsultaisn in the animals lato which it is transplanted. This 1s currently belng studied by Dr. Chick of the Joslin Diabetes Foundation in cozlaboration with us and by $\mathrm{Dr}$. Like of the University or Massachusetts Nedical School. Among other aspects the insulin content of the tumor is being detexmined.

B. 2. Irradiated Transplants of Human Cancer Cells-A number of transplantable human tumors that have been irradiated beavily in the past have been maintained in the Institute's frozen tissue bank. Sanples are periodically tested for viability and constancy of arpbology.

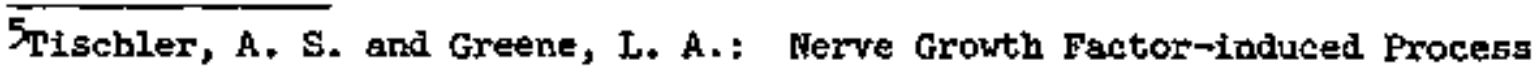
Formation by Gultured Rat Pheochronocytoma Ce11s. Nature 258:341-342, $11 / 27 / 75$. 
PUBLIOATIONS SUPPOAIED BY

ERDA COATRACT $\dot{\mathrm{E}}(11-1)-3017$

MEW ENGLAND DEACONESS HOSPICAL

15 MARCH 1975 - 15 MARCH 1976

Porter, M. W., Chute, R. H. and

Warren, S.:

Harren, S.:

Warren, S.:

Warrea, S.:

Publications in Press

Porter, M. W., Chute, R. H. and Warren, S.:

Warten, S.:

Werrea, S.:

Warren, S., Brown, C. E. and Chute, R. N.:
Abstract: The Incidence of Radiation-Induced Cataract in Single and Parabiotic Rats. Radiation Res. 62:544, 6/1975.

Skeletal and Tissue Lestons Resulting from Exposture to Radium and Fisston Froducts. Ann. Cirn. Lab. Sci. 5:75-8l, 3-4/1975.

Autopsy Techniques for Recognition of Radiation Injury, Bull. Soc. Pharmacological \& Environmentel Pathologists III:9, 6/1975.

Effects of Low Levels of Radiation on Rodents and Potential Effects in Man. Health Fhysics $29: 251-$ 255, 8/2975.

Incidence of Radietion-Induced Cataract in Single and Parabiotic Rats. Rediation Res.

Effects of Occupational and Environmental Exposures to fonfzing Radiation. Chagter in Forensic Meaicine:A Study in Traums and Environmental Fazards. Ed. by C. G. Tedeschi, I. G. Tedescht and W. G. Eckert, .. B. Saunders Co., Philacielpbla.

Safe Handling of Tissues Containing Radioactive Substances. Ann. Clin. Lab. Sci.

Parabiosí, Radiation and Carcinogenesis in the Rat. I Tunori. 
Warren, S. and Gates, 0.:

Leukemogenesis by Low-Level Radiation. Proceedings of IAFA/Who

- International Symposium on Blological Effects of Low-Level Radiation Pertinent to Protection of Man and His Enviromment, Chicago, Ill., $11 / 1975$. 